\title{
Frederick Dalton (1815-80): Uncovering a life in gold
}

\section{BRENDAN DALTON}

My father died in 1997 at 70 years of age. He had grown up without a father. In 1927, a few months after my father's birth, my grandfather Herbert Arthur Dalton died. The male influences in my father's early life were his maternal unclesthe Leonards-and the Christian Brothers. He grew up with a very strong sense of his own history as fundamentally Irish Australian, Catholic, working class and, in spite of his name, as a Leonard. Dalton being a fairly common Irish name, he assumed that his father's family had the same background. For my father there was pride in this ancestry; pride based in the love he felt for the unpretentious, deeply religious, funny, heroic (World War I being a very big part of his family story) and loving people, the aunts and uncles that he had known. While he may have been comfortable with this story, my father felt its contradictions, at times deeply.

We have one photograph of my Dalton grandfather, bending to reward a happy and well-trained dog: an Airedale. The man is already 50, tall, in a dark suit and moustachioed in the style of Henry Lawson, almost stereotypically 'Australian' from the period before World War I. His look could not be more different to the big-eared, long faces and shorter statures of the Leonard males. I have known this photograph all my life and I also know that my father rarely looked at it. Perhaps the mystery of his father was too great and the need to know more, too profoundly insatiable.

Apart from the photograph, my father knew some facts of his father's life: that he had worked for the financier and company director Sir John Garvin; that he had managed Garvin's rural properties and had trained his polo ponies. My grandmother was in service in one of the Garvin households where the two had met and, in 1922, married - my grandfather was 47 and my grandma, Barbara Catherine Leonard, was 23. As a small boy my father said that he had once met one of his Dalton aunts, an encounter not fondly recalled with a tall woman dressed in black; the encounter had scared him. He knew very little about his grandparents, only that his grandfather, Frederick, had some official position at Forbes and that there may have been an obituary in a Sydney newspaper.

In the mid-1980s my father suffered from several serious medical conditions. A discussion with my doctor about family medical history led me to realise how little I knew about the Daltons. So, on a cold, grey, Canberra day in July, seeking shelter in the National Library of Australia, I talked to a librarian about the meagre 
scraps of information I had on Frederick Dalton. I was able to browse the stacks for the thick blue volumes of the New South Wales (NSW) Police Gazette. Within 20 minutes, references began to appear to appointments as a gold commissioner, police magistrate and warden in places like Uralla (1860), Nundle (1864), Forbes and Grenfell (1867 and beyond). On a later visit, the librarians took me to the microfilm readers to review issues of the Sydney Morning Herald (SMH) and other colonial newspapers. If you have experience in searching through an unindexed nineteenthcentury newspaper on a microfilm reader, you will know how headache-inducing it is to search for one name. Among the jumble of news, editorials and obituaries, no reference appeared to Frederick Dalton. However, among the advertising from January 1881, a large government notice stood out, seeking information on the whereabouts of Frederick Dalton Esq., police magistrate, Forbes. ${ }^{1}$

This revelation of my great-grandfather's disappearance was shocking: a senior official late in his career vanishing without a trace. For his family in 1880 his disappearance must have been devastating. Combined with my grandfather's late marriage and relatively early death, his disappearance also provided a possible explanation for our lack of knowledge about our Dalton relations. The information suggested there was much more to be discovered, but I still had little understanding about what a gold commissioner, police magistrate or warden was, or about Frederick Dalton's life. That is where my research may have stayed. However, in 2012 a professional interest in technology, and a suggestion from my eldest brother, led me to the historic newspapers searchable through the National Library of Australia's Trove web portal. Entering details relevant to what I knew of Dalton's life, immediately I began to uncover more detail on him than I had imagined existed, not just his appointments and promotions, but information about his career, his family, and, eventually, his thoughts and views of the communities he worked in. Equally important, I was able to identify a series of articles in the $S M H$ as almost certainly the work of Frederick Dalton. $^{2}$

\footnotetext{
1 Evening News (Sydney), 10 January 1881, 1.

2 There are about 90 articles in the series, most using the byline 'Special Reporter' common in goldfields and other special reports in the Sydney Morning Herald from the gold rush era. The series covers tours of the Western, Southern and Northern goldfields over a period of two years from mid-1858. Giving a wealth of detail on the goldfields and goldfields life, these articles are well known and widely quoted. Authorship, however, has been unclear because of the nineteenth-century practice of not naming journalists. I had come across references to Dalton having written for Fairfax, but I had not been able to attribute articles to him. In early 2014, based on two references to a Mr Dalton of the Fairfax Company making donations to the Sydney Museum of geological specimens from specific locations I was able to triangulate the locations, times and nature of the specimens with articles from the same locations, at the same times and referring to the same geological issues. I have since found more circumstantial evidence for his authorship; Dalton taking up his first gold commissioner position in Uralla, at about the time that the articles stop, also in Uralla. More recently I have used Trove to find references from a Tasmanian newspaper in the 1870s to a Mr Dalton who had written from Adelong in 1859 (in turn referencing Rev. W. B. Clarke's 1860 book which used Mr Dalton's analysis, see note 22) and made accurate predictions based on geological analysis; this appears to reference the southern goldfields tour also in 1859. Lastly, with the help of Dr Peter Crabb (researching another gold commissioner journalist and colleague of Frederick Dalton, Charles de Boos), I was put in touch with research being undertaken by Dr Alexis Antonia from the University of Newcastle who is using software to analyse digitised texts. Her analysis shows that the $S M H$ articles from the goldfields between 1858 and 1860 use very similar language, grammar and style to later documents from the 1870 s authored by Frederick Dalton.
} 


\section{A dinner at Grenfell}

Located 350 kilometres south-west of Sydney, Grenfell was proclaimed on 1 January 1867 and, by 1877 , was a settled and prosperous community of several thousand citizens. During its first decade, it had contributed millions of pounds to the wealth of the colony. The town's foundation, wealth and population all sprang from gold. The town was situated on the site of the original gold diggings astride Emu Creek, a few kilometres north-east of the Weddin Mountains. Europeans had settled the area in the late 1830s establishing a few large sheep stations. ${ }^{3}$ The area continued to be home to Aboriginal people as it had for tens of thousands of years, but by 1877 their presence was recorded only in newspaper reports of proceedings in the magistrate's court.

At $9 \mathrm{pm}$ on Monday 11 June 1877 a banquet was held in the town to inaugurate the new court of quarter sessions and to welcome its new judge. For the town in its tenth year, it was also a coming of age celebration. A local journalist described the festivities:

There were roast turkey, duck, fowl, tongue, with vegetables, including green peas. There were vases filled with fragrant flowers as ornament ... There was every variety of puddings, tarts, custards, jellies, oranges, apples, pears, muscatels, and nuts. Nor should we omit to mention the abundance and excellence of the wines, spirits, ale and porter, and the superior manner in which everything was served. In each department all was of the best class, and the wants of the guests were anticipated by the alacrity and care of a numerous and skilful body of attendants. ${ }^{4}$

Presiding over the feast was the police magistrate Frederick Dalton. At 62 he was already suffering the consequences of a hard life, with years spent working on goldfields and camping in the bush on several continents. He had been associated with Grenfell from its beginning, describing his first night in the area in November 1866:

It was then so much of a wilderness that [I] had some difficulty in finding the locality of the goldfield. Literally there was no road to it. Upon [my] arrival [I] managed to obtain shelter for a night under a sheet of bark. ${ }^{5}$

3 Brundah station, originally surrounding the town of Grenfell to the south-east, was taken up by Mr John Butler Wood at the age of 17 in 1836. Two years earlier Wood, from an established squatter family, was one of the first whites to explore the area. His reminiscences, published after his death, describe the large Aboriginal population of the area, and the tension between the newcomers and the original inhabitants. The frontier was only 'settled' after violence and murder on both sides, but with shockingly callous, murderous tactics employed by some of the squatters and their shepherds. A description can be found in the Grenfell Record and Lachlan District Advertiser, 14 January 1919, 2.

4 Grenfell Record and Lachlan District Advertiser, 16 June 1877, 2-3.

5 Grenfell Record and Lachlan District Advertiser, 16 June 1877, 2-3. 
The Weddin or Emu Creek rush was big, and government, after more than a decade of rushes, was quick to see the need to bring order to the field. So Dalton, an experienced gold commissioner and police magistrate, was ordered to station himself there. There is no record of how he spent his second night on the field, most likely he gave up his sheet of bark for a tent and quickly had a site marked out for his official residence on what became known as Camp Hill. In December he was briefly joined by the gold commissioner from Forbes, 20 miles to the north, who reported favourably on the field and quickly left. ${ }^{6}$ A surveyor had also been sent and his energies ensured the basic street plan of the town of Grenfell had been laid out before the end of 1866 . These were temporary visitors; Dalton's job was to stay.

A journalist from Bathurst visited in January 1867 and described the goldfield at the height of its first summer, with a population of over 5,000 diggers:

A cloud of dust was hovering over the town as if from some mighty conflagration ... dust was omnipotent and accompanied by a fiery sun and strong wind the reverse of pleasing or delightful. ${ }^{7}$

The noise of mining operations was incessant. A rush site was a place of intense physical activity, with miners digging and sometimes blasting through rock, often only a few feet from where they slept. Amid the maelstrom the new boom town was forming:

The town of Grenfell extends some two miles already, and is hourly lengthening at each end ... In it are situated the principal buildings, the two banks ... upwards of forty public houses all licensed, some built of iron, some of weatherboards, some of bark, while others are composed of all three together, and some even consist of a few poles held together by stout calico. ${ }^{8}$

\section{Frederick Dalton Esq: A biography}

Frederick Dalton had been a world traveller, digger, social commentator, columnist, geologist and goldfields magistrate. An influential public figure, his activities were well documented in the newspapers and official journals of his time. The lives of many of his friends and colleagues are recorded in the Australian Dictionary of Biography, but fate, and the nature of his contribution to early Australian public life, meant that his life and work has been largely forgotten. In 1872 in evidence to the NSW royal commission into the regulation of gold mining, Dalton (then a goldfields magistrate of over 10 years standing) stated that he had arrived in the

\footnotetext{
Illustrated Sydney News, 15 December 1866, 3.

Empire (Sydney), 8 January 1867, 5.

Empire (Sydney), 8 January 1867, 5.
} 
colony in 1853. Mr Robert Masterton Vaughn, justice of the peace at Grenfell and soon to be member of the NSW Legislative Assembly, was vice chairman of the banquet on that winter night in 1877 . In one of his several speeches he recalled:

How strangely things came about in this world ... he first met their worthy Chairman, Mr Dalton, many years ago, when crossing the plains from the Atlantic to the Pacific, in the States of America, both then on their way to another land of gold and excitement. ${ }^{9}$

That Dalton came to Australia from California is corroborated by Vaughn and others, but little else is certain about his early life. He claimed to have been born in Edinburgh in 1815, his father Colonel Tudor Dalton. His later writings suggest that he had been educated in Scotland and that he was well read. He seems to have had knowledge of literature, history, science, economics and theology, and his understanding of theoretical and practical geology at a time when the science was in its infancy suggests training, but no evidence for this has been found. It is also possible that, as well as the United States of America (USA), he travelled throughout the United Kingdom and Europe.

Dalton had crossed the Pacific to get to Sydney after spending time in North America: 'In the year 1852 I travelled through the Utah territory, situated in the heart of the great American desert, 1200 miles from the nearest abode of civilized man'. ${ }^{10}$ Calling himself a 'settler' in the USA, his writings suggest he had been there and in Canada for some years before his journey to California. He may have held some kind of official position in California in relation to gold, or he may have been there simply as a digger. Dalton admired but was also critical of the USA, in particular 'the insecurity of life and property; the ordeal of blood, anarchy, and confusion that every State founded by the American Union has passed through' ${ }^{11}$ His criticisms of the American frontier may have had a personal element. In reminiscences, he was described on several occasions as having a malformed or wry neck. In at least one account this was attributed to him having run afoul of the lynch mob in California: did a mob attempt to hang him? It certainly made a good story but his wry neck may have also been caused by one of many riding accidents. We know that Dalton had a very personal experience of frontier lawlessness. He describes being caught up in frontier tensions in the Utah Territory where, 'my being mistaken for a Yankee nearly cost me my life, proving myself an Englishman saved it' ${ }^{12}$

In 1852 news of the discovery of gold in NSW reached the west coast of America, and by 1853 Dalton was in Sydney. Between 1853 and 1858 he tried his luck in search of gold on the Victorian fields, in northern NSW and in southern Queensland. In

9 Grenfell Record and Lachlan District Advertiser, 16 June 1877, 2 - 3.

10 Sydney Morning Herald, 26 January 1859, 3.

11 Sydney Morning Herald, 20 April 1859, 5.

12 Sydney Morning Herald, 26 January 1859, 3. 
all likelihood, he is the Mr Dalton described as one of the discoverers of the diggings at Fairfield not far from Tabulam. ${ }^{13}$ In 1856 he married Rosa Lavinia Wood; he was 41 and she was 18 . Two years later their first child was born at Tabulam and Dalton recorded his profession on the birth certificate as 'farmer'. He may have tried farming after some success as a prospector. His intimacy with the problems faced by 'new chum' farmers attempting to replicate modern 'scientific' farming techniques in the bush is reflected in one of his $S M H$ columns: 'A saying ... current both in the Canadas and the Western States, that the 'emigrant capitalist farmer must first be ruined before he can succeed', and experience justifies the assertion'. ${ }^{14}$

Dalton's next decision in mid-1858 was to leave hearth and home for two years. Opting for a steady income, but often a bed under the stars, he took on the job of a goldfields columnist for the $S M H$. His first column was a description of the 'Western Road' out of Sydney and over the Blue Mountains to the western goldfields, the settlements along the way, the geology and appearance of the landscape, the engineering of the roads, its bridges and the mountain passes. From the start he commented on NSW society as he found it and as he thought it could be.

Dalton seems to have stayed on the goldfields of the western slopes of the Great Dividing Range for almost a year. In his articles, collectively titled 'A Visit to the Western Goldfields', he travels up the water courses talking to diggers, describing their habitations, the sites of rushes and former rushes, the towns that are beginning to be established, and the characteristics of the Chinese, Australian born, European and American diggers. He gives detailed descriptions of the geology and geography of the gold bearing regions, information on what the digger will find there, and the prospects for gold, based on the author's geological analysis.

13 Sydney Morning Herald, 17 March 1858.

14 Sydney Morning Herald, 28 January 1859, 3. 


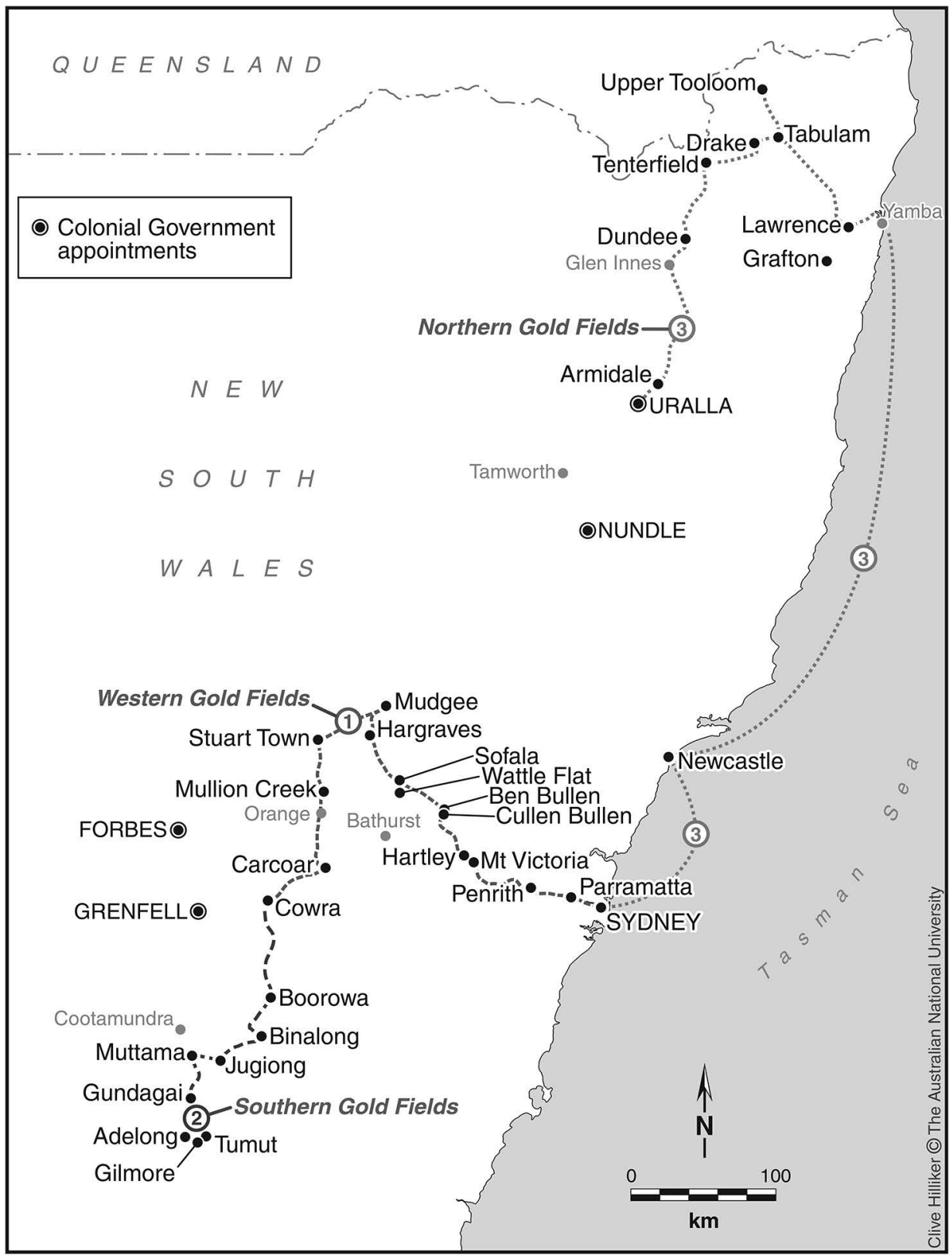

Figure 1: Frederick Dalton's recorded travels in NSW, the gold regions he wrote about and the towns where he and Rosa were based in the course of their public service career. In his year on the western goldfields his route followed the watercourses criss-crossing the mountainous tableland to the north of Bathurst. His travels to the south and north followed the more direct routes shown.

Source: Map reproduced with the kind permission of Dr Peter Crabb and Clive Hilliker, Fenner School of Environment and Society, The Australian National University. 


\section{Dalton the journalist}

During 1859 Dalton travelled south to the foothills of the Snowy Mountains and the gold town of Adelong, writing a series entitled 'A Visit to the Southern Goldfields'. In his final series, 'A Visit to the Northern Goldfields', he travelled up the Clarence River to the northern goldfields, Tabulam and beyond, almost to the Queensland border, ending in early 1860, the last article posted from Uralla in northern NSW. ${ }^{15}$ SMH columnists rarely received attribution and Dalton's authorship of these articles went unrecognised until 2014. There are regular references to his writing and work as a geologist of gold in the newspapers for the decade after his columns appeared. His views on gold in quartz from the goldfield at Adelong are quoted by the Rev. W. B. Clarke, sometimes styled the father of Australian science, in his 1860 book Researches on the Goldfields of Southern Australia. ${ }^{16}$ The gold rushes were mass movements of diggers, informed mainly by rumour and luck, and little influenced by scientific analysis. Dalton's writing brought a level of empirical analysis backed by theory to $S M H$ readers. He covered each of the major fields of NSW and commented on prospects elsewhere, informed by Clarke and Count Strzelecki's earlier work on the geology of NSW. His geological explanations were detailed and perhaps dry for a lay audience, but he sought to demystify science. After a discussion of the chemical and geological process that led to the creation of the quartz reefs at Adelong, he commented that:

Long dissertations written upon the dipping and rising of quartz reefs, according to some geometrical rule, will, I fear prove to be as the philosopher's stone of the middle ages. Nature is a simple chemist, and varies her productions according to the materials upon which she operates. ${ }^{17}$

A few weeks before Charles Darwin's publication of On the Origin of Species, Dalton shared with his reader a profound sense of awe at the scope of geological time observable through science. Still in the bustling boom town of Adelong, he wrote:

If a granite pebble could write its history, what man's life would suffice to enable him to read, to follow it in its varied migrations during the lapse of a thousand ages through the incandescent fires of the new born earth, the ocean's depths, and the wreck of continents. ${ }^{18}$

15 As well as the formally titled "A Visit to..." articles, there are several stand-alone essays and three articles about the trip from the western fields south to Adelong, each individually tilted according to the main towns he encountered on the way.

16 Rev. W. B. Clarke, Researches on the Goldfields of Southern Australia, (Sydney: Redding and Wellbank, 1860).

This work may owe more to Dalton's influence than attributed; for example, Clarke's chapters on the economics of gold mirror articles written by Dalton in the previous year.

17 Sydney Morning Herald, 28 September 1859, 8.

18 Sydney Morning Herald, 19 September 1859, 2. 
He was equally interested in other themes, in particular how the gold mining industry could be improved with appropriate government support. In one example (again from Adelong), he called on the government to provide more scientific support for the diggers by the appointment of a government chemist to advise on the extraction of gold from ore. ${ }^{19}$ Appropriate forms of government assistance to the mining industry would be a topic of public debate over the next decade.

Dalton's columns engaged with the other political topics of the day, including state support for the Church of England, education and land reform. He was a member of the Free Church of Scotland, which argued that state support had led the established church to become remote from its people and their communities. Dalton and his fellow believers thought that NSW, with its new and increasingly democratic selfgovernment, was in a position to change the status quo inherited from the United Kingdom. His travels through NSW gave him a unique perspective on rural society and allowed him to develop the theme of bringing Christianity to the goldfields and rural NSW as a necessary condition to the establishment of a civil society. This could be done, he believed, by providing state support for all Christian sects (with the exception of Mormonism) to support the foundation of rural churches. ${ }^{20} \mathrm{He}$ painted a sometimes bleak picture of rural life dominated by ignorance, lawlessness and alcohol-induced indolence. In addition to a Christian ministry, he advocated state support for education. He wrote about what he saw and, in so doing, brought the plight of rural communities before his audience, adding fuel to the reformist fire:

How the unhappy children are fed is a mystery; that they are fed somehow is pretty certain as they are numerous, their little spare forms and joyless faces may be seen scattered amongst the huts, or gathered in groups listlessly passing away the precious hours under the shade of some huge log; poor children, theirs is a dreary existencenurtured in ignorance, familiarised with vice from their cradle, unhabituated to the restraints of civilization ... The country is responsible to the Christian world for the education of these infants; while we are splitting hairs, weighing atoms, and battling for the supremacy of dogmas or creedless systems of education, they are fast approaching a state of primeval barbarism, and their benighted and lost souls will cry to Heaven for vengeance upon those who have thus left them to perish. ${ }^{21}$ 
Dalton maintained that government land distribution policies, little changed from those of a colonial plantation society dominated by large landholders, were very much to blame for the state of rural society:

We have hitherto been endeavouring to build a house by commencing at the garretto plant a nation without a yeomanry — and what have we produced[?] Let any man visit the clusters of pothouses in the interior, miscalled towns and villages. ${ }^{22}$

His use of the word 'yeomanry', introduced in his first column, advertised his views in a political debate that had been underway for over a decade, and aligned his thoughts with reformist circles in Macquarie Street and Westminster. Samuel Sidney, in his popular 1852 work The Three Colonies of Australia, wrote:

Australia was a country in which any industrious man could thrive; that there was ample verge and room enough for millions; that land which squatters then and now assert to be only fit for sheep pasture would support yeomanry in comfort and independence. ${ }^{23}$

Sidney believed that Britain's vanishing 'pastoral arcadia inhabited by sturdy 40 acre yeomen ... could be revived in Australia'. ${ }^{24} \mathrm{He}$ was influenced by Charles Dickens, whose own widely popular magazine expressed similar views about the opportunities in Australia. Dickens and Sidney joined literary forces with Australian reformers like Caroline Chisolm, linking social and land reform in Australia to a broader political reform agenda in Britain. ${ }^{25}$ Perhaps because they were brought up on the art and literature of romanticism, this notion of an idealised, lost British arcadia struck a chord with mid-Victorian readers and it permeates much of Dalton's writing. Dalton took up the cause of land reform in rural NSW, with the digger cast as yeoman. His writing and his thoughts on reform are underpinned by a social and economic framework combining scientific advice to industry, assisting a landed and thus self-sufficient digger to better direct his energies, and creating wealth in Christian communities and generating sustainable economic growth for NSW. Although his focus was on the goldfields, Dalton also explored the idea of reform within a larger context - the economic and social development of Australia. He expressed his disgust of colonists who were ignorant of its beauty and potential:

\footnotetext{
22 Sydney Morning Herald, 19 August 1859, 2.

23 Samuel Sidney, The Three Colonies of Australia: New South Wales, Victoria, South Australia; Their Pastures, Copper Mines and Gold Fields, 2nd ed. (London, 1853; Project Gutenberg of Australia, 2014), gutenberg.net.au/ ebooks 14/1400441h.html.

24 Robert Hughes, The Fatal Shore: A History of the Transportation of Convicts to Australia 1787-1868 (London: Pan Books in association with Collins, 1988), 558.

25 Hughes, The Fatal Shore, 559.
} 
Some soulless biped in Victoria is reported to have deliberately written that 'Australia is not worth fighting for'. Has he ever witnessed the glories of her sun-lit mountains, the broad and fertile valleys, the noble forests, the grassy plains, and the countless streams of her interior the future happy homes of millions of our race as yet unborn? Has he had no visions of future empire, of the destiny that awaits our children in this noble land? ${ }^{26}$

Throughout his columns, Dalton wrote about his overseas and particularly his American experiences. His observations on North America display a detailed knowledge of goldfields technology, river transport on the Ohio and Mississippi, forestry and road engineering in California and Canada, and an understanding of frontier history. His descriptions were intended to provide examples particularly of technology and innovation that could be productive in Australia. In one article Dalton noted that he had been asked by his editors to review land distribution practices on the USA frontier. ${ }^{27}$ His account was not sympathetic, highlighting arbitrariness, a lack of sympathy for the individual and the potential for the system to be manipulated by the rich, better informed or better connected. Why did the $S M H$ want this analysis and, more broadly, why was a conservative publication interested in accounts that continually called for social and political reform? The special reporter was considered to have expertise on America. The SMH's purpose in seeking this specific column was to dispel myths circulating in the colony about the superiority of the USA's system. More generally perhaps, its columnist's views suited a conservative journal that saw that, on the back of the major population boom brought by the gold rush, some form of reform was required to maintain social cohesion. ${ }^{28}$ Reform for Dalton did not require revolution or separation from the Crown. His views on land reform are framed within a fundamentally English constitutional model that sought stability through continuity, and the creation of self-sufficient Christian communities in a fundamentally British, imperial world.

Without further research it is difficult to judge the influence of Dalton's columns. They did not seem to spark debate in letters to the editor, but they were referenced in other discussions and on occasions were reprinted in other publications. In a media landscape in which the newspaper was the only form of public information and entertainment, the columns were produced almost fortnightly over two years in one of the largest circulation newspaper of its day. Significantly, Dalton was appointed as a gold commissioner in the early weeks of the reformist administration of Sir John Robertson, who was elected in March 1860. His was clearly a political appointment and Robertson, as both premier and minister for lands, delivered a land reform bill that conformed to Dalton's views, opening up land for small-scale farming.

\footnotetext{
26 Sydney Morning Herald, 26 August 1859, 2.

27 Sydney Morning Herald, 8 June 1859, 4.

28 Perhaps Dalton's reform politics also coincided with an attempt by the paper to take circulation away from Henry Parkes's struggling and more reform-centric journal Empire.
} 


\section{Dalton, the gold commissioner}

In mid-1860 Dalton's columns ended abruptly, the last being from the Rocky River goldfield in northern NSW, less than 2 kilometres from Uralla. Two months later the newspapers announced his appointment as a sub-commissioner at Uralla. ${ }^{29}$ The administrative system had been in place since the earliest days of the gold rush in NSW, when John Richard Hardy was appointed commissioner on the first diggings at Ophir near Bathurst. ${ }^{30}$ As police magistrate, he was empowered to raise a force of special constables, collect licence fees from diggers and to 'protect those engaged in digging' ${ }^{31}$

By the time of Dalton's appointment eight years later, there were 23 commissioners on the NSW goldfields, comprising three chief commissioners, 11 assistant commissioners and nine sub-commissioners. ${ }^{32}$ Gold commissioners were appointed for two-year terms and the positions were keenly sought. Initially, many were retired military officers or men whose family background and connections in the United Kingdom gave them 'gentleman' status in the colony. The Police Gazette of 1860 listed Dalton’s annual pay as $£ 300$ plus expenses for the upkeep of his horse. Gold commissioners were well-paid men of authority and status.

The Rocky River was an important goldfield and, at its height, there were thousands of diggers working the reefs on Mount Walsh and Mount Jones, as well as the alluvial workings along the river. Larger and more established goldfields such as 'the Rocky' had a commissioner's camp that may have included accommodation for the officers, and accommodation and stabling for mounted police troopers and their horses.

\footnotetext{
29 Sydney Morning Herald, 14 July 1860, 4.

30 Nancy Keesing, 'Hardy, John Richard (1807-1858)', Australian Dictionary of Biography, National Centre of Biography, The Australian National University, adb.anu.edu.au/biography/hardy-john-richard-3715/text5831, published first in hardcopy 1972, accessed online 6 April 2015.

31 Sydney Morning Herald, 29 September 1851, 2.

32 Hon John P. Hamilton QC, 'History of Gold Commissioners in NSW', oldmountainltd.com.au/historycommissioners-gold-nsw.
} 


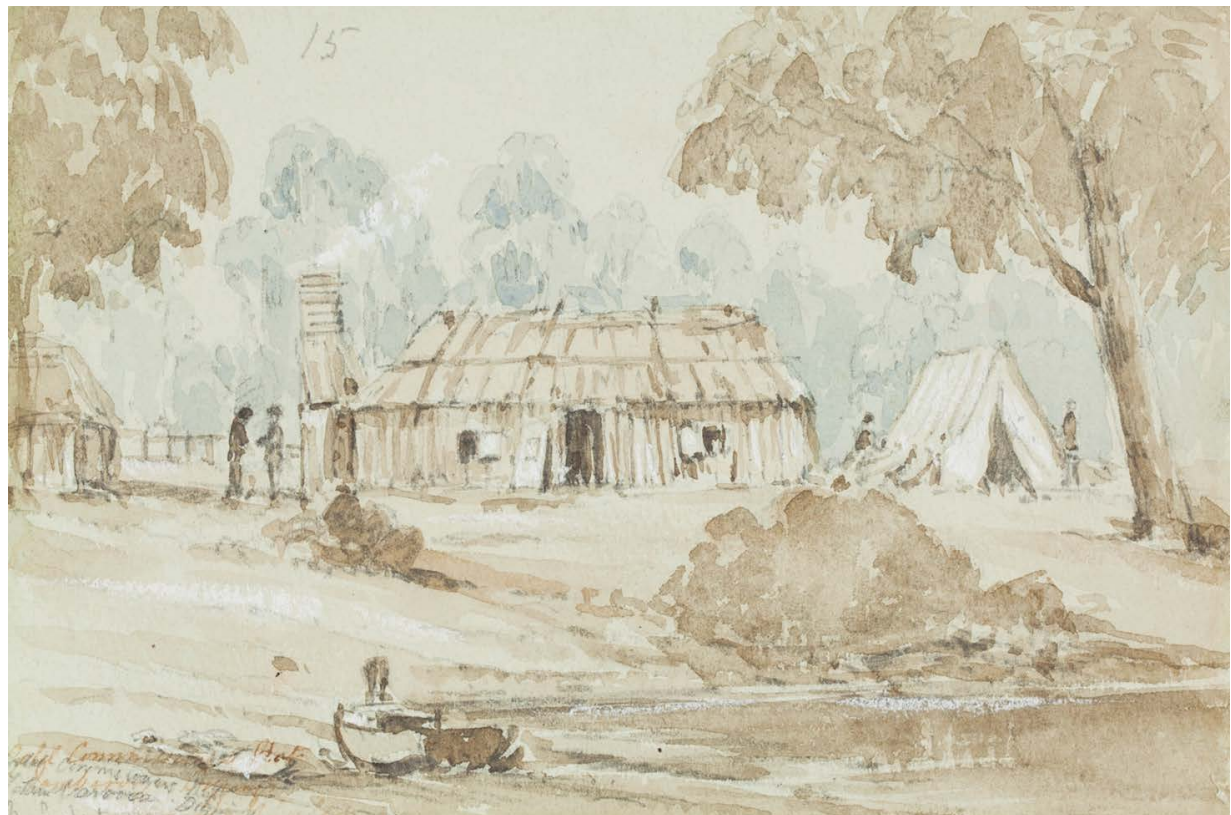

Figure 2: Commissioner Hardy collecting license fees.

Source: George Lacy, The First Commissioner Hardy Collecting Licenses and Diggers Evading (1851). Courtesy National Library of Australia, nla.pic-an3103343-v.

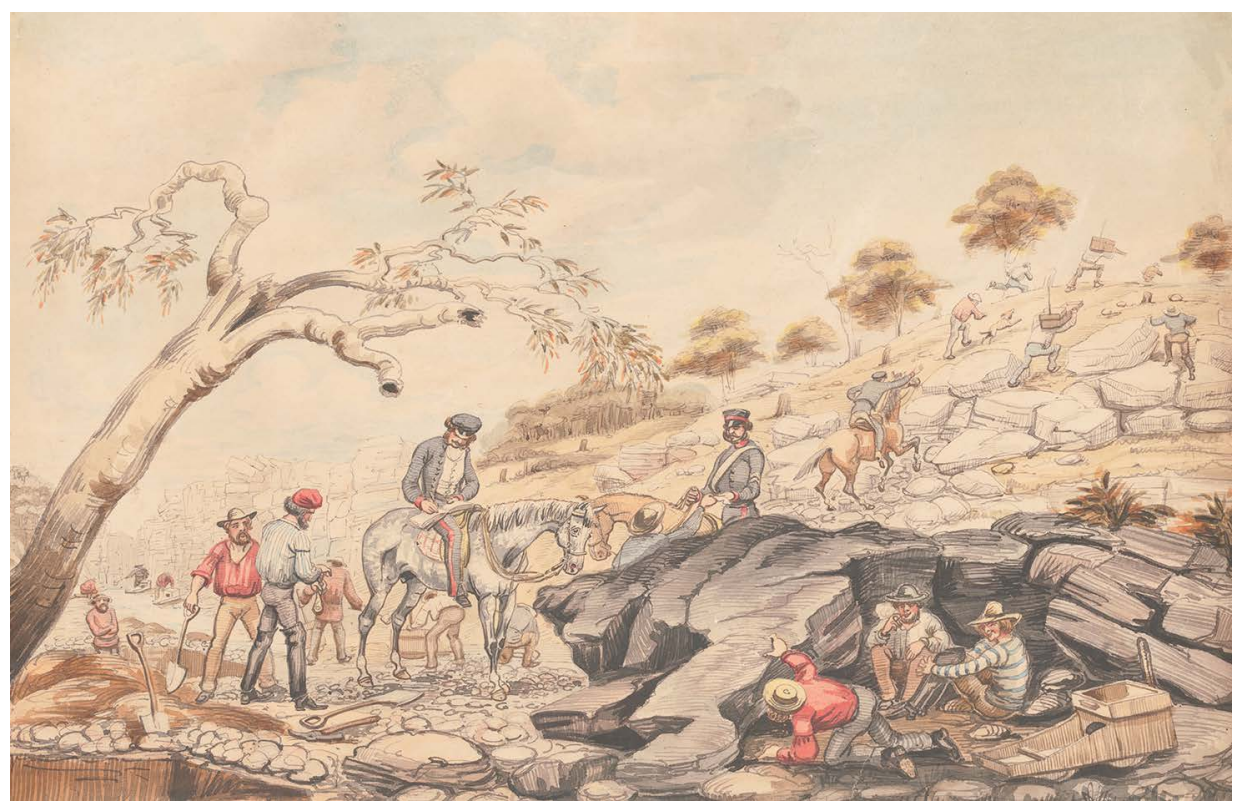

Figure 3: A gold commissioner's hut and commissioner's camp. Dalton wrote about the unprepossessing nature of Australian bush architecture.

Source: Henry John Douglas Scott, Gold Commissioners Hut Tambaroora Diggings, ca April 1853 / Henry Scott Montagu, 1st baron (1853). Courtesy State Library of New South Wales. 
Uralla became Dalton's base for several years. Rosa joined him and the growing family moved with him as his public service career took him to different goldfields in the northern gold regions. Newspaper reports show them working together to develop the civic institutions that Dalton had seen as lacking in rural communities. As early as December 1861, the Freeman's Journal noted preparations for a visit to Uralla by the Catholic archbishop:

The interior arrangement of the Church is not completed, and too much praise cannot be bestowed upon Mr and Mrs F. Dalton, for their indefatigable exertions in extemporarily making the requisite arrangements for holding Divine service. ${ }^{33}$

The sub-commissioner's work life was largely on horseback, travelling up and down the creeks and rivers, visiting other sites a few day's ride from Uralla. Accidents and falls from horses were common. Dalton fell from his horse or buggy on several occasions, at least once requiring a period of recuperation due to a 'concussion of the brain'. ${ }^{34}$

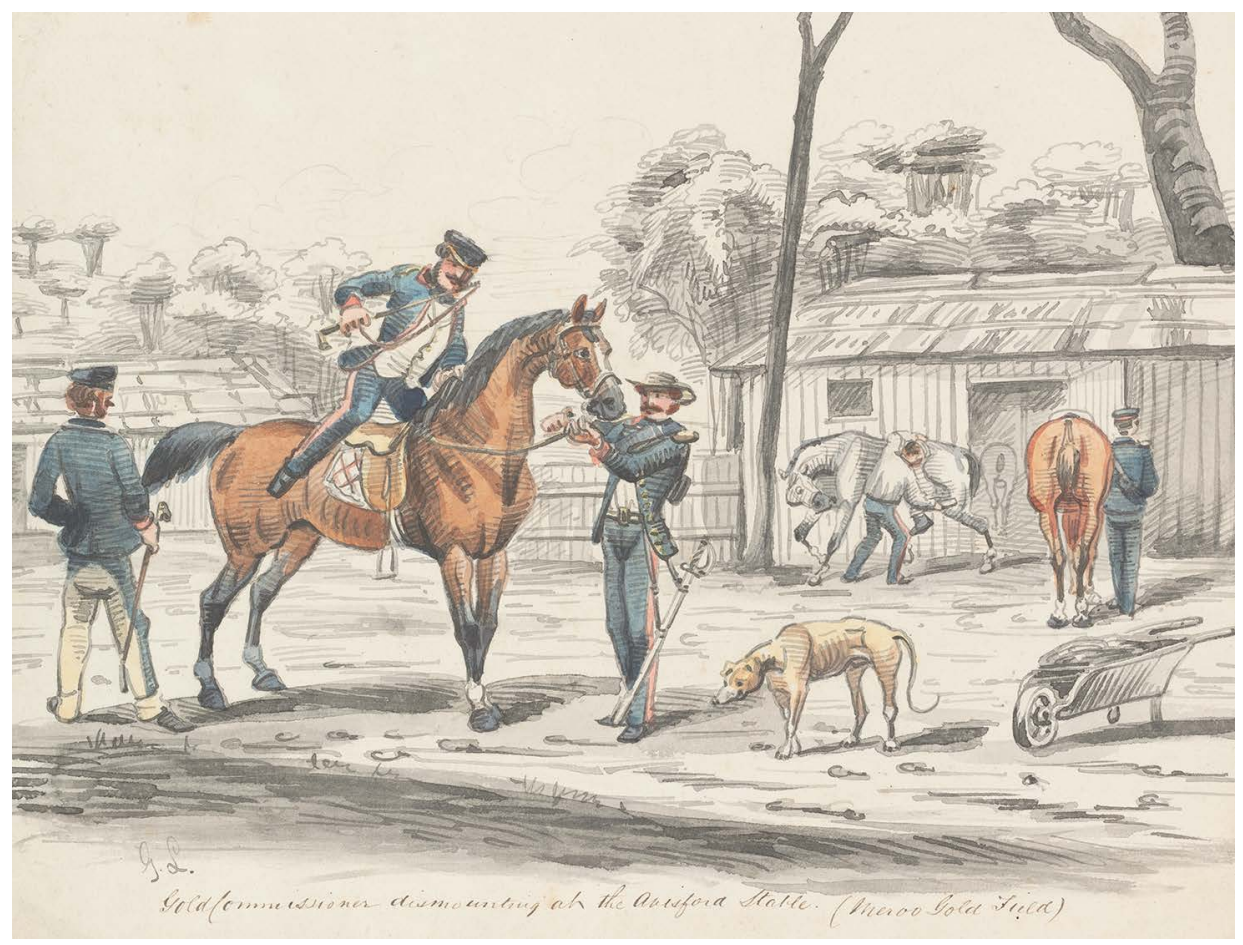

Figure 4: Gold commissioner getting off his horse. This image from the 1850 s suggests an alignment with the military.

Source: George Lacy, Gold Commissioner Dismounting at the Avisford Stable, Meroo Gold Field (1850). Courtesy National Library of Australia, nla.pic-an3103592-v.

33 Freemans Journal, 21 December 1861.

34 Argus, 27 January 1862, 7. 
As a columnist, Dalton had pointed out the lack of scientific advice available to the digger. In September 1863 Dalton was on the Woodsreef field and the SMH noted:

$\mathrm{Mr}$ Dalton, as is well known to most people in the Northern district, is a geologist of great experience, and his opinion of the richness of this goldfield, expressed by him some time ago, is being pleasingly verified in the increased quantity of gold obtained from the alluvial diggings. Alluvial work previous to Mr. D's arrival here was nearly totally neglected, but ... his judicious suggestions ... [are] resulting ... in increased remuneration to the workers. ${ }^{35}$

Dalton's geological advice to the diggers set him apart from his colleagues. These activities were well reported and do not seem to have come into conflict with his duties as a magistrate and regulator.

In December 1864 at age 49, Dalton was promoted to assistant gold commissioner and police magistrate at Nundle, 100 kilometres south of Uralla. ${ }^{36}$ As a magistrate he investigated a much reported murder at Bowling Alley Point, a mining village on a bend in the Peel River a few miles north of Nundle. The case shocked Australia. Mrs Butler, the wife of an innkeeper, had been stabbed in her bed in a frenzied attack:

An inquest was to have commenced before Mr Gold Commissioner Dalton on Wednesday last, so that the facts connected with the dreadful deed will doubtless soon be revealed ... Mrs Butler, the wife of an innkeeper ... had been murdered ... In one of the rooms of the inn, lying on a single bed, the clothes on which were completely saturated with blood, the body of the unfortunate woman covered with stabs in almost every part. The body was dressed in the usual night dress, as if the deceased had retired to rest ... The body presented a most horrible sight. From the appearance of the clothes on the bed, a terrible struggle must have taken place ere death ensued. ${ }^{37}$

In April 1862, in an incident reported as the 'Forage Investigation', Dalton provided evidence of corrupt practices by his superior James Buchanan, the chief gold commissioner in northern NSW: 'one of the charges against Mr. Buchanan, as proved. Mr. Dalton, the sub commissioner, had complained that twelve bags of corn had been received at the camp; without weighing'. ${ }^{38}$ Buchanan, who resigned, was initially found guilty after a local enquiry. On appeal to the court in Sydney, the charges were dismissed. Buchanan subsequently stood for and won the northern goldfields seat in the NSW Parliament at the 1863 election. ${ }^{39}$ His election and possible antagonism to Dalton may have had an impact on Dalton's career. In late 1865, Charles Cowper formed a new government with an agenda to cut

35 Sydney Morning Herald, 2 September 1863, 8.

36 Maitland Mercury and Hunter River General Advertiser, 6 October 1864, 3.

37 Queanbeyan Age and General Advertiser, 27 July 1865, 3.

38 Examiner (Kiama), 22 April 1862, 3.

39 Newcastle Chronicle and Hunter River District News, 22 April 1863, 3. This was the election in which it was rumoured that Frederick Dalton might also stand for the same seat. 
government spending. The government concluded that gold commissioner functions could be carried out more cheaply by unpaid justices of the peace. The services of 14 commissioners were dispensed with in $1866 .{ }^{40}$

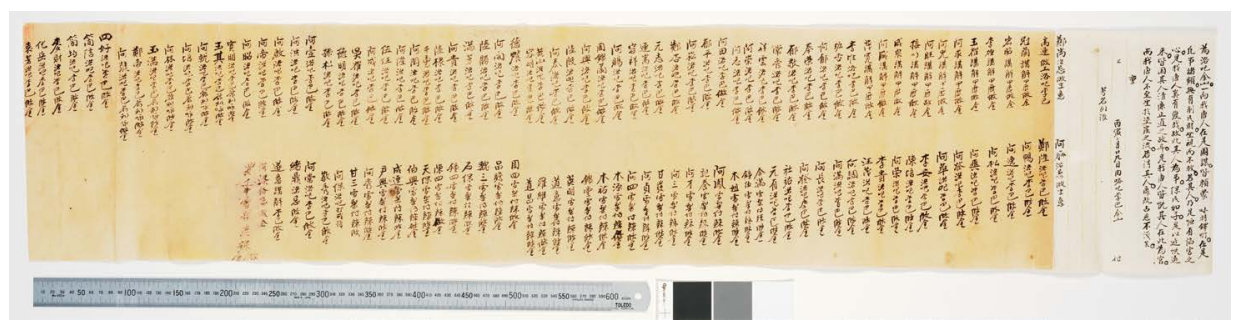

Figure 5: Image of the petition from the Chinese residents on the Rocky River to retain Dalton as a commissioner. The original 1.2 metre scroll is held by the NSW State Archives.

Source: Courtesy State Archives of NSW.

There were representations from the diggers and shopkeepers of the northern goldfields to keep Dalton, but they were ignored, perhaps because many of the petitioners were from the friendless and discriminated-against Chinese community. ${ }^{41}$ The SMH suggested politics had played a hand and that he had lost his position because he lacked friends or had enemies in Sydney. ${ }^{42}$ In 1866 Dalton turned 51 and, by early November, he and Rosa were living in Sydney, where he was referred to as the 'former Gold Commissioner, Nundle'. We know this from a well-reported personal tragedy: the death of their four-year-old son Frederick Dalton junior, who had fallen from a cart in Devonshire Street, Surry Hills. ${ }^{43}$

A few weeks later Dalton's professional fortunes had dramatically changed when he was appointed police magistrate to a new rush, several hundred kilometres southwest of Sydney. On 1 January 1867, the site of the rush was proclaimed as the new township of Grenfell. Newspapers suggested that a population of 20,000 could be expected, but it was a time of drought and conditions on the field were tough. For Dalton, conditions were at best, rudimentary. A journalist commented:

The Court house is the most extraordinary specimen of building I ever saw; it is simply some stout forked poles ... these are crossed by other saplings, and on the top of this a heap of boughs, just to shade the sun off. The magisterial chair was ... once ... a candle box set on end ... the table was formed of the lid of another box fixed on the top of four forked sticks ... Mr. Dalton holds high court at this unique courthouse, and the public stand all round to hear the police business, two men were under examination for robbery $\ldots$ and there must have been a crowd of not less than $500 .^{44}$

40 Sydney Morning Herald, 9 June 1866.

41 Sydney Morning Herald, 9 June 1866.

42 Sydney Morning Herald, 26 January 1866.

43 Sydney Morning Herald, 6 November 1866.

44 Maitland Mercury and Hunter River General Advertiser, 10 January 1867. 
As a police magistrate, Dalton was kept busy with the administration, not just of mining regulations, but also all aspects of government administration. In January 1867 the newspapers reported him hearing a case of attempted murder and robbery. ${ }^{45}$ Other early cases show him attempting to resolve conflicts between miners and squatters. ${ }^{46}$ His workload grew rapidly:

With a population of nearly 5000 persons, it is unjust to expect one man to administer the law in all its forms, without an unreasonable demand being made upon his time. I do know positively, that fourteen hours a day is below the average time now occupied in the discharge of the multifarious duties imposed on the Police Magistrate. $^{47}$

In February 1867 Dalton's responsibilities were expanded to include the Forbes police district 65 kilometres to the north. ${ }^{48}$ At 52, he again became something of an itinerant administrator, travelling regularly between Grenfell and Forbes and other outlying population centres. He was to spend the next 17 years in the central west of NSW. In late 1869 his base was moved to Forbes, the more established centre. ${ }^{49}$ While this caused grumbling in Grenfell, the implications for Dalton in his middle 50s were significant. ${ }^{50}$ For most of the following decade he was consistently styled as the police magistrate for the Lachlan, responsible for the administration of justice and mining regulations over a vast territory. By 1874 he was described as the gold commissioner for the Billabong goldfield (later Parkes) and police magistrate for Grenfell, Forbes, Condobolin and Lake Cargelligo. The distance between Lake Cargelligo and either Grenfell or Forbes is close to 250 kilometres. In a horse drawn age, the trip to Lake Cargelligo would have taken the better part of a fortnight, camping in the bush on the way. There are descriptions of Dalton travelling further west than Cargelligo undertaking geological surveys. He also travelled east, on one occasion as far as Mount Canobolas near Orange. ${ }^{51}$ Within this area, and for a population of between 15,000 and 40,000 people (the population fluctuated with the rushes), he was the primary judicial and administrative officer.

There were further rushes around Grenfell and Forbes, at Lake Cargelligo and beyond. In the early 1860s the town of Currajong had sprung up around a rush. In 1871 Dalton was asked to visit the area to confirm a new rush. Bushman's Lead

\footnotetext{
45 Empire, 18 January 1867, 5.

46 Empire, 11 February 1867, 5.

47 Sydney Morning Herald, 15 June 1867, 7.

48 Sydney Morning Herald, 20 February 1867, 5.

49 In late 1869 the town of Grenfell held a farewell meeting at which they presented their police magistrate with a gold watch (Sydney Morning Herald, 12 October 1869, 5); by 1870 he was stationed at Forbes, where he had been instructed to reside because of the greater 'distribution of population in the district of Forbes' (Empire, 3 September 1870, 3).

50 This controversy requires further investigation as some newspaper accounts state that he was again retrenched in late 1868. If so, he was reappointed a few months later as police magistrate at Forbes and also retained all of the responsibilities he had held while stationed at Grenfell.

51 Clarence and Richmond Examiner and New England Advertiser (Grafton), 16 December 1876, 3.
} 
became one of the richest goldmines in the colony. The premier, Henry Parkes, visited Forbes and Currajong in 1873. In both places, Dalton escorted him into town accompanied by a contingent of local mounted police. As a sign of his standing in both communities, Dalton made the welcoming speeches, presided over the banquets and conducted the visitors on tours of the towns. ${ }^{52}$ In honour of the premier's visit, Currajong's name was changed to Parkes.

Dalton's official headquarters remained at Forbes. His responsibilities in Grenfell diminished with the arrival of the court of quarter sessions and the activity of the local justices of the peace, whom he had trained, ${ }^{53}$ but he remained a frequent visitor to adjudicate mining disputes. At Parkes, where the population reached 20,000, he visited for several weeks at a time in his circuit around the region. While there, he lived in one of the hotels and set up his court room in another. In late 1866 a journalist visiting the Emu Creek field described Dalton going about his duties:

Mr Dalton seems a great improvement on the old Bashaw style of commissioner. When you call upon him to decide a dispute he is not away playing billiards, nor does he consider it necessary to eye you over in the Simon Tappertitt ${ }^{54}$ style before attending to business ... disputes are heard impartially by $\mathrm{Mr}$ Dalton, and investigated with pain and courtesy of manner without the necessity of men touching their hat continually or putting 'sir' to every expression ... You see a mob of men about every quarter of an hour in the day, about a dozen of whom are gesticulating fiercely ... and four or five challenging their opponents to single combat. The commissioner, or rather police magistrate ... is sent for. Down he comes post haste, the row ceases; a pause of a few moments two or three men are sworn; a few, terse questions are put; the regulation briefly commented on bearing on the point in dispute; the decision given in six words and before the disputants can look round them, the mining judge is a hundred yards off to another little mob, at the top of the gully who are going through the same exciting game..$^{55}$

In his earlier articles, Dalton had been critical of the gold commissioners who were depicted as remote, absent from the field, or off hob-knobbing and perhaps colluding with the squatters against the interests of the diggers. When he became a gold commissioner, he seems to have taken his own criticisms very much to heart. A digger's primary objective was to find gold. Maintaining the peace on a goldfield could best be achieved by keeping the diggers at their work and by the speedy, public resolution of disputes. The goldfields judges were intended by government to be authority figures. The only descriptions of Dalton come from the Police Gazette at the time of his disappearance at the age of 65 . He was described as 6 feet tall, with steel grey whiskers and a distinctive military bearing. ${ }^{56}$ Commissioners and police

52 Sydney Morning Herald, 22 August 1873, 3.

53 Grenfell Record and Lachlan District Advertiser, 5 June 1909.

54 A reference to the Dickens character 'Barnaby Rudge'.

55 'From the Weddin Diggings', Empire, 17 December 1866, 5.

56 NSW Police Gazette December 1880. 
magistrates wore military style uniforms - a connection intended to suggest that the goldfields were under a form of para-military control. The goldfield magistrates had real power. They controlled, or at least could command, the local mounted police forces, and had the power to detain members of the public, who had no recourse to trial by jury; nor did defendants in most cases have access to professional representation in court. Remote from Sydney and with limited oversight, it is no wonder that these men could abuse their power and become, at least in the journalists' perception, like the archetype of their Ottoman counterparts, lazy, partisan and prone to arbitrary decisions.

Dalton was not immune from criticism and had enemies. By mid-1869, for reasons that remain unclear, at least some of the community in Grenfell were keen to have him replaced. In another instance a memoir depicted him, perhaps from late in his career, as being sarcastic in his dealings with miners. ${ }^{57}$ Yet, in a Trove search yielding nearly 1,000 references to Dalton in contemporary newspapers, these comments are rare exceptions. Overwhelmingly, he is depicted as 'a practical miner and practical commissioner, shrewd and quick in detection of any defect, but careful in dealing out justice, off-handed, kind, and conscientiously just' ${ }^{58}$

Dalton's adherence to the Free Church of Scotland, with its emphasis on leadership within and not remote from a community, influenced the way he went about his work, and the broader role he developed as a community leader, helping to establish churches, education and healthcare in the growing towns in his region. Dalton saw the need for frontier communities to develop within a framework of tradition. An incident in his first year at Grenfell shows little tolerance for those who would challenge established mores:

Mr Dalton made it his business in going to the proprietor of the theatre and told him if he allowed a lecture to take place he would commit him to gaol for three years. ... [T]wo persons waited on Mr Dalton at his place of residence, and enquired his reasons for such conduct, when he told them his reason was that Tom Paine's works were to be read to the public, and he would not allow it. ${ }^{59}$

Some Grenfell residents were caught off guard by their magistrate's response and Dalton was accused by some of high handedness. As a magistrate his job was to enforce the authority of the Crown, but there was something more to this incident. Dalton, in his earlier writing, depicted England's economic and social traditions as a model for a peaceful and prosperous NSW. At the other end of the scale, the capricious and sometimes brutal forces he had observed in the settlement of the USA frontier were as the antithesis of orderly and peaceful development. Like the majority of his reform minded peers, Dalton was a confident son of the British

57 Grenfell Record and Lachlan District Advertiser, 31 October 1916, 2.

58 Australian Town and Country Journal, 28 October 1871, 7.

59 Mining Record and Grenfell General Advertiser, 3 August 1867, 2. 
Empire, proud of England's traditions and a loyal subject of Queen Victoria. As some residents on the Grenfell diggings found, Dalton's world had no place for the words of the old republican and revolutionary, Thomas Paine.

By the 1870s alluvial and near surface mining was becoming a thing of the past. Mining became more scientific, more of an industry and, while prospectors remained, miners led more settled lives as employees rather than lone operators. Dalton's columns had predicted this future as well as the need for investors to support more complex mining ventures. His columns strongly supported a role for government, reducing the risk to investment by providing specialist scientific advice. His own public career shows his efforts to advise diggers. It would be interesting to know whether more private advice was provided across dining tables, to the burghers of Forbes, Grenfell and Parkes. That Dalton pursued a bigger role for government in supporting the industry is clear. In 1879 at his instigation, his superiors provided a grant of $£ 250$ to support a team of prospectors in the hope of finding new leads, 'the men agreeing to work wherever, the Government inspector, Mr. Dalton, elected'. ${ }^{60}$

In January 1872 Dalton went to Sydney as a member of a committee of officials advising on new goldfields regulations. ${ }^{61} \mathrm{~A}$ new system to regulate mining had been proposed as one of the major recommendations from a long running royal commission. ${ }^{62}$ This recommendation was to establish a number of mining regions each administered by a warden. The new system was implemented in the Mining Act 1874 (NSW). The new regulations removed the old system of gold commissioners and Dalton became one of the first of the new mining wardens. In this role, he presided over a mining court that met at standard times. This was a more professional and more regular judicial system of regulation. Rulings were published, the warden's courts were supported by clerks and other judicial officers, with plaintiffs often represented by lawyers.

Dalton's territory remained large and while he had more support in the form of clerks of petty sessions, and JPs in the population centres, he was still required to travel large distances to administer justice. In September 1879 the newspapers reported his new two-year appointment as the warden of mines and police magistrate at Forbes. ${ }^{63} \mathrm{He}$ and Rosa were living outside Forbes at a property called Sunnyside with their large family of 11 children. In late 1879 he attended the marriage of his eldest daughter into a prosperous Sydney family. Perhaps he was thinking of retirement; however, in accepting the appointment, he was also accepting another two years of almost constant travel, responsibility for a region of tens of thousands of square kilometres and tens of thousands of souls.

60 Australian Town and Country Journal, 8 November 1879, 23.

61 Sydney Morning Herald, 19 January 1872, 4.

62 Royal Commission of Inquiry into the Working of the present Gold Fields Act and Regulations of NSW and into the best means of securing a permanent water supply for the Gold Fields of the Colony, 1870-71 [NSW State Archives].

63 Australian Town and Country Journal, 27 September 1879, 13. 


\section{Last drinks}

The communities under Dalton's jurisdiction prospered. The towns celebrated their prosperity and, as first citizens, he and Rosa sponsored banquets, picnics and galas at Grenfell, Parkes and Forbes. We are lucky to have so much detail on the banquet at Grenfell in June 1877. It was clearly enjoyed by all who attended. The food and wine, accompanied by music and singing, was topped off by toasting and formal joviality. The twenty-fourth recorded toast was given by the vice chairman of the welcoming banquet, Mr Robert Matterson Vaughn JP. ${ }^{64}$ A digger of long standing, he had also come from California in 1853 to try his luck on the Australian goldfields. At Grenfell he decided to throw in his lot with the colony by becoming a British subject. This allowed him to buy land and become a local magistrate. For most of the decade preceding the banquet, he and other local landowners (mainly the pastoralist J. Wood JP) had assisted Dalton in the administration of justice in the region.

In Vaughn's speech of thanks at the banquet, he commented:

He had lived to see the place pass through the different phases that occurred to nearly all gold fields. First we had the whirl and excitement that attends the stage of getting rich claims, and a great deal of gold. Then came the usual state of depression that always follows the failure of the mines. Then came the steady, gradual improvement that follows other and more permanent industries, and we now see a state of prosperity that most persons acquainted here in the early days never anticipated ... When he came to Grenfell, about the first man he met, that he knew, was Mr Dalton, after years of separation, during which both had passed through the usual hardships and trial that attend the life of gold seekers; and now we meet again this evening, and have the honour to mutually thank you for the kindly manner in which our names are mentioned in connection with this banquet. ${ }^{65}$

Fifteen years Dalton's junior, Vaughn was later elected a member of the NSW Legislative Assembly. The two had met as wanderers half a world away and were now burghers, solid, wealthy citizens of communities they had themselves forged.

In 1880 Dalton turned 65. The previous year had brought mixed blessings. He had enjoyed the marriage of his eldest daughter, but had also suffered an accident, being thrown from his buggy on the road from Parkes to Forbes. Although suffering from increasingly poor health, in September 1880 he was well enough to undertake a police enquiry into a suspicious death at Condobolin. After a month away

64 Justice of the peace and later member of the Legislative Assembly for Grenfell. Ann-Mari Jordens, 'Vaughn, Robert Matterson (1833-1908)', Australian Dictionary of Biography, National Centre of Biography, The Australian National University, adb.anu.edu.au/biography/Vaughn-robert-matterson-4774/text7943, published first in hardcopy 1976, accessed online 17 September 2018.

65 Grenfell Record and Lachlan District Advertiser, 16 June 1877, 2-3. 
and a trip of 100 kilometres back to Forbes, he set off again almost immediately. He told someone that he was heading west but instead went south by public coach. The official reporting states he was last seen at Harden-Murrumburrah, suffering from ill health and poor eyesight. The official reporting suggests he caught the train south, but he was never seen again. ${ }^{66}$

An investigation must have taken place and there are records in the NSW, Victorian, South Australian and Tasmanian police gazettes seeking information on his whereabouts; what happened to him? He is recorded as having withdrawn a very large amount of money, 200 sovereigns, from his bank account just prior to his disappearance, at least double the average annual male wage in 1880 . There were suggestions many years later that he was 'much harassed by domestic troubles and worried by family expenses' ${ }^{67}$ The train journey from Murrumburrah south, even today, winds through very isolated country, and in 1880 much of it was heavily forested. Travelling alone and in increasingly poor health Dalton was vulnerable. Perhaps the lure of such a large amount of money was too much, and he was robbed, killed and his body disposed of on a stretch of isolated track?

Dalton's life and work provide insights into some significant and little discussed questions of Australian history and culture. His work and writing enlighten understandings of the formation of the public service, government attitudes to science, the development of the mining industry and the responsibility of the state for education. He wrote as a commentator and worked as a crown official at a time of profound change in Australia - in population, in economy and at a time when many of the civic patterns that we recognise and expect today were being established. Dalton was very much a part of this change.

As an official, he was responsible for settling thousands of individuals into new communities. This peaceful movement and settlement is remarkable in itself, but Dalton's writing also played a part in establishing the conditions for that settlement, highlighting significant issues for NSW society outside the capital. He proposed a different vision for settlement, one of social cohesion and economic growth. Dalton's ideas were part of a British liberal tradition evolving in the mid-nineteenth century, seeking reform within the English system, not revolution. It drew on idealised English traditions of authority and was supported by a romantic historicism in English art and literature. He saw this liberal vision as foundational to the British Empire- a foundation myth. But these ideas were not purely mythic; they sought to provide a practical and common sense framework for the settlement of Australia.

66 There were suggestions that he had caught the train on to Melbourne and then took a ship out of the country. Several year later, reports that he was seen at Manly beach in Sydney, and that bones found while building a new hotel in Murrumburrah were his proved to be dead ends. The lack of reporting of a formal investigation is surprising, and may have led to the speculation that the government knew more about his disappearance. Many police records from the period, in both Victoria and NSW, were destroyed in the 1960s.

67 Grenfell Record, 4 April, 1921, 2. 
Writing for the $S M H$ from the western goldfields, somewhere on the Turon River, in 1859, Dalton told his readers:

I have a promised task to perform; a digger's widow has solicited me to write an inscription for the tombstone of her husband. He rests in the golden earth where he laboured, amidst the glooms of the wild and tangled forest, 'God has spoken, and the strong heart she leaned upon is broken. ${ }^{6} 8$

For most of his professional peers, the story of their lives ends in a printed summation; a death notice, an obituary, but not for Dalton. ${ }^{69}$ For him the trail of words continues sporadically for a few decades until those who remembered him were gone. ${ }^{70}$ Like the goldfields where he spent his energies, the print story of his life petered out. If he had the opportunity to write his own epitaph what might he have said? With his faith in the future of his adopted country and its future generations, I suggest that he would have simply used the practical words he wrote on leaving the grave site on the Turon: 'It is done and we will go forward'.

\section{Postscript}

Frederick Dalton's story ended at Murrumburrah in November 1880, but the life of the man who went by that name continued. Shortly after completing this article I received an email from Wendy Levot, an experienced genealogist and also an ancestor of Dalton. She told me that he had adopted the name as an alias in 1857 soon after marrying Rosa, and that his real name was Bartholomew Frederick Lloyd. Rosa was also involved in this change of identity, and subsequent research suggested some of the reasons. The crucial piece of evidence unlocking the mystery to Frederick's disappearance was a birth record for Rosa and Frederick's second child

68 'A Visit to the Western Gold Fields No. VIII'. Sydney Morning Herald, 21 January 1859, 2. Dalton does not identify the site of the grave although in the context of the articles it cannot be far from Sofala.

69 No obituary has come to light. Several years after his disappearance, Rosa was awarded a $£ 500$ annuity by the NSW Parliament. Within his family the only story about his disappearance that has survived is told by the descendants of one of his elder daughters who, after marriage, travelled to the United Kingdom. It relates that he was killed by bushrangers while protecting a shipment of gold; a story that echoes the true story of Dalton's colleague, Gold Commissioner Grenfell of Forbes, in whose posthumous memory the town was named. Rosa, with four children under the age of ten, struggled with the loss of her husband. Unfortunately, it was not the only seismic family shock she had to deal with in her later life; her eldest daughter divorced, under what would be considered 'scandalous' or, to my more sympathetic view, tragic circumstances. Rosa died in 1901 in Sydney; her youngest son, Herbert Arthur Dalton, completed the details for her death certificate. The confused details it contains strongly suggest that Herbert had little contact with his older siblings and knew little of Rosa and Frederick's life, his father having disappeared when he was six years old.

70 There are several reminders of Dalton's life and work. Grenfell and Parkes have a Dalton Street. In Grenfell it is now a dusty laneway off George Street, the old main street. Dalton Street in Parkes is one of the main streets in the town's CBD. A current Parkes resident also recalls stories of the old magistrate, told to her by her father. Such stories include how Mr Dalton accompanied the premier into town, how he was the miner's friend and how he disappeared mysteriously (although she was told that the government really knew what had happened to him). More prominent than all of these is the petition from Chinese miners now available on the State Archives of NSW website and his writings for the $S M H$; often quoted for the detail they provide on gold rush history. 
Emily. While there is no birth registration for an Emily Dalton, there is a birth registered for an Emily as the child of Bartholomew Frederick and Rose Lloyd. ${ }^{71}$ The registration matches much of what we know of the Daltons. The baby is recorded as having an older sister, Sarah Louisa, born 18 months earlier, matching the date of birth of Sarah Louisa Dalton. The registration records the father's employment as 'journalist' and this also fits with Frederick Dalton who was working on his series 'The Western Goldfields' for the $S M H$ at the time. The likelihood that Dalton and Lloyd were the same person has been strengthened by DNA evidence linking the Australian Dalton and Irish Lloyd families, through textual analysis of Lloyd's and Dalton's writing, and by the many links in Dalton's life story and that of Lloyd.

So who was Bartholomew Frederick Lloyd? Fredrick was born in 1810 at Athy, Ireland, into a large and well-connected family of Church of Ireland clerics and academics. ${ }^{72}$ His father, Robert Lloyd MD, was a Trinity-educated physician. ${ }^{73}$ In 1818 he was at Cambridge University and by 1821 he lived and had a practice in Grosvenor Square in London. ${ }^{74}$ At 15 Frederick Lloyd was a midshipman in the Royal Navy ${ }^{75}$ and, after five years at sea, spent the next 20 in business as a publisher, map maker and stationer. In 1833 in London, he married Mary Anne Bull and over the next 20 years the couple had six children. Moving the family to Edinburgh in the early 1840s he established his business as 'B. F. Lloyd and Co.', and tasted material and professional success that also placed him in social proximity to the small but dynamic scientific and intellectual life of the city. In Edinburgh in the 1840s he experienced at first-hand the religious reform movement in the Church of Scotland. The year 1848, though, was one of economic depression, and the threat of bankruptcy forced the sale of both his personal and business assets. Frederick

71 New South Wales Registry of Births, Deaths and Marriages: registration number 803/1859: birth of Emily J. Lloyd, Sydney.

72 Sir Bernard Burke, A Genealogical and Heraldic History of the Landed Gentry of Ireland, rev. A. C. Fox-Davies (London: Harrison and Sons, 1912) contains a detailed genealogy of the Lloyd family. Details under the heading 'Lloyd of Lossett', pp. 411-13. Close family members held positions of power and influence in British society in the course of the nineteenth century. An uncle, Rev. Humphrey Lloyd DD, and his cousin Rev. Bartholomew Lloyd DD, were both Provosts of Trinity College Dublin, noted educationalists and, in Bartholomew's case, a much praised mathematician and physicist. Another first cousin, John Thomas Ball QC, was a Tory MP who was attorney-general under Benjamin Disraeli and went on to become the chief legal officer for Ireland. Multiple references including the Oxford Dictionary of National Biography.

73 Robert commenced at Trinity College in 1800 at the age of 15 . He was a 'pensioner', meaning that he held a scholarship from the university. He was awarded a BA in 1805 and $\mathrm{MB}$ and MD in 1817. George Dames Burtchaell and Thomas Ulick Sadlier, eds, Alumni Dublinenses: A Register of the Students, Graduates, Professors and Provosts of Trinity College in the University of Dublin (1593-1860) (Dublin: Alex. Thom \& Co., 1935), 507, digitalcollections.tcd.ie/home/index.php?DRIS_ID=LCN10378529_0003.

74 For references to Robert's career see 'Robert Lloyd', Lives of the Fellows, Royal College of Physicians, 2009, accessed 23 September 2018, munksroll.rcplondon.ac.uk/Biography/Details/2779. See also The Royal Kalendar, and Court and City Register for England, Scotland, Ireland, and the Colonies 1824 (London: William March \& Son, 1824), 283 and 394; and for confirmation of London address and an interesting investigation of Robert's activities as a dissector, see report on a coronial inquest in Globe, 12 July 1821, 4.

75 Royal Navy personnel transcriptions, HMS Sparrowhawk, 1829; search.findmypast.com.au/record?id=gbm \%2frn1831\%2f35126; HMS Icarus: search.findmypast.com.au/record?id=gbm\%2frn1831\%2f35125. 
immigrated with his family to the USA where he started afresh as a stationer at Chicago. In 1852 with his wife's blessing - and possibly spurred by the death of his second son Frederick - he and his eldest son, Horace, joined a wagon train heading for California. Misadventure followed, first on the prairie where Horace went missing and was presumed dead, and later when, as mentioned previously, an incident in Utah led perhaps to him being robbed. ${ }^{76}$

Lloyd's misadventures in California led him to start afresh and so he took ship from San Francisco, arriving in Sydney in July $1854 .{ }^{77}$ A few months later he was running a storehouse at Maryborough supplying goods for the coastal cane farms and newly established runs in the interior. Between 1854 and 1856, under the name 'B. F. Lloyd', he advertised his business in the Sydney press, and later wrote a letter to the editor expressing his opinion about Maryborough, and seeking fairer treatment of the Aboriginal population. ${ }^{78} \mathrm{He}$ came to Australia down on his luck, but the evidence suggests that in his first two years he prospered in Sydney and Maryborough. In May 1856 Lloyd married Rosa Lavinia Montgomery at Maryborough; ${ }^{79}$ he was still married to his first wife, Mary Anne, who was alive and well, and living in Chicago. Perhaps, Frederick married Rosa imagining that his past life, family and connections could remain anonymous in this distant outpost of empire. Unfortunately for him, he was not the only member of the Lloyd family in Oceania. One of his first cousins, Rev. John Frederick Lloyd, was rector of Saint Paul's in Auckland, New Zealand. In an environment in which colonial newspapers were widely circulated, it is likely that, having seen his cousin's name in the $S M H$, Rev. J. F. Lloyd tried to contact him. The name 'B. F. Lloyd' also brought with it a business reputation, and for more than a decade had been a prominent presence on Hanover Street, Edinburgh. For much of the 1840s, and before that in a partnership as 'Caldwell and Lloyd', his name was associated with publications and stationery products that were widely advertised in newspapers and sold across Britain. ${ }^{80}$ However, B. F. Lloyd had been bankrupted. Newspaper advertisements notifying the world of his status as a bankrupt are still

76 'Another Enoch Arden', Iron County Register (Ironton, Montana), 5 October 1882, 6.

77 New South Wales, Australia, Unassisted Immigrant Passenger Lists, 1826-1922, 12 June 1854, vessel Arnaud.

78 The letter was headed 'Wide Bay' and signed 'B. F. Lloyd, Maryboro, 25 $5^{\text {th }}$ November 1854'; it was written in response to an article in an earlier edition of the paper. Sydney Morning Herald, 15 December 1854, 4. For other newspaper advertisements for the business, see Sydney Morning Herald, 10 March 1856, 1; 11 March 1856, 1; 12 March 1856, 1; Empire, 10 March 1856, 1; 11 March 1856, 1; 12 March 1856, 1.

79 New South Wales Registry of Births, Deaths and Marriages: registration number 1655/1856: marriage of Bartholomew Frederick Lloyd and Rosa Lavinia Montgomery, Maryborough, Wide Bay, New South Wales.

80 Throughout most of the 1840s, numerous advertisements for the company's products appeared in British newspapers, first for Caldwell, Lloyd \& Co. and then, from January, 1844, for B. F. Lloyd \& Co. For example, Morning Post (London), 1 November 1841, 1; Scotsman (Edinburgh), 11 June 1842, 1; Bell's Life in London and Sporting Chronicle, 12 June 1842, 1; Scotsman, 24 January 1844, 1; Aberdeen Press and Journal, 31 January 1844, 2; Sheffield Independent, 18 October 1845, 11. 
discoverable on the internet today. ${ }^{81}$ Bankruptcy was a significant social stigma for a gentleman and perhaps this taint on his reputation had been pointed out to him as he sought to establish himself in business in NSW.

Frederick's marriage to Rosa seems to mark a decision to stay in Australia and assume the life of a gentleman and member of the colonial elite. In this context, Rosa's family background might also have created challenges. Rosa (or Rose as she was probably known) had been born in Australia in about 1838 to John Montgomery and Sarah (Sally) Donnelly. ${ }^{82}$ Both had been convicts from the north of Ireland, John had been transported for life for crimes against a landowner, ${ }^{83}$ and Sarah, a former servant, for seven years for theft from her employers. ${ }^{84}$ John and Sarah probably never married, but the couple had five children over more than a decade, and lived near Windsor, west of Sydney. By the 1850s Sarah seems to have become an alcoholic and a petty criminal; only a few months after Rosa's wedding, she died from alcohol poisoning in Darlinghurst gaol. ${ }^{85}$ Rosa's brothers were also less than model citizens, with one continuing to live on the wrong side of the law well into the $1870 \mathrm{~s}^{86}$

In 1857 Frederick left Maryborough and started to establish himself under his new name. For the next 23 years, he and Rosa had a family, made friends and contributed to the development of Australia as the Dalton family. The year 1879, though, was a big year for the family and it may have been these events that led to Frederick's decision to 'disappear'. His eldest daughter had married, requiring not only a wedding befitting her family's standing, but also a dowry payment. There had been an addition to the family with the birth of another daughter, and Fredrick now had eight children to provide for; there is evidence that his family commitments were straining his finances. ${ }^{87}$ His brother-in-law, Rosa's older brother, became an outlaw in 1879 , and was shot and killed by the police. Added to these trials, he was in poor health, and so, on top of financial stress, and concerned that Rosa's siblings would bring him into disrepute, perhaps he just wanted to get awayto return 'home' to Britain for his final years? A few months after his mysterious disappearance in 1880, B. F. Lloyd reappeared in London recuperating at Guy's hospital and claiming to be a former sugar planter from Queensland. In London, Frederick may have reconnected with members of the Lloyd family. At some point he learnt that his son Horace had not been lost on the prairie after all. After an

\footnotetext{
81 For examples of the bankruptcy notices, see Morning Post (London), 20 December 1848, 4; Perry's Bankrupt and Insolvent Weekly Gazette, 23 December 1848, 984; Perry's Bankruptcy Gazette, 23 December 1848, 983; Scotsman, 10 October 1849, 1; Inverness Courier, 28 December 1848, 4.

82 John Montgomery's death registration.

83 See for example Ticket of Leave, 19 May 1830, NSW State Record Office NRS12202.

84 See for example Certificate of Freedom 10 September 1832, NSW State Record Office 12210.

85 There are multiple sources for Sarah's continuing brushes with the law through the 1840 s and ' 50 s. The inquest into her death was widely reported, see for example Empire, 22 September 1856, 4.

86 Multiple references to James Montgomery and horse theft; see for example NSW Police Gazette No. 28, 9 July 1879,264 , which gives a description of his death.

87 Grenfell Record, 4 April 1921, 2.
} 
absence of 30 years, in 1882, Frederick returned to his family in Chicago where he found Horace, his daughters, grandchildren and his first wife Mary Ann. His return and the tall (and mostly inaccurate) tales of his adventures were recorded by a local newspaper and reprinted across the USA. ${ }^{88}$ Mary Ann and her family were never told about his younger wife and his many children in Australia. He lived until 1886, surviving both Horace and Mary Ann, who died within 18 months of his reappearance. Today, an impressive headstone stands under an oak tree in the city's Rosehill cemetery, beside that of Mary Anne and his American children. Meanwhile in Sydney, Rosa’s final resting place is unknown.

88 'Another Enoch Arden', Iron County Register, 6. 
This text is taken from Australian Journal of Biography and History: No. 1, 2018, published 2018 by ANU Press, The Australian National University, Canberra, Australia.

doi.org/10.22459/AJBH.2018.06 